\title{
АНТИРЕЛІГІЙНА ПОЛІТИКА РАДЯНСЬКОЇ ВЛАДИ В КІНЦІ 20-Х - 30-ті РОКИ ХХ СТОРІЧЧЯ (НА ПРИКЛАДІ РИМО-КАТОЛИКІВ ДНІПРОПЕТРОВСЬКА)
}

Анотація: У статті висвітлено умови, в яких існувала Дніпропетровська римо-католицька парафія св. Йосипа в кіниі 20-х - 30-ті роки ХХ ст. У ией період влада впроваджувала політику, характерними рисами якої були посилення антирелігійної пропаганди, масове закриття культових споруд, репресії проти католищьких священників і польського населення.

Ймовірно, римо-католицька спільнота Дніпропетровська проіснувала довше більшості громад Південної України. Точна дата закриття костелу в обласному центрі, на жаль, невідома, але наведені аргументи дозволяють найбільш вірогідною датою вважати кінець 1936 року. Через відсутність документів немає можливості точно описати механізм закриття названого храму, можна лише «намалювати схему» цього процесу, користуючись документами про ліквідацію костелів в інших містах Півдня та Сходу Украӥни.

Останній удар по парафії св. Йосипа нанесли репресії 1937 року, в результаті яких вона на певний час припинила своє існування.

Ключові слова: римо-католики, Дніпропетровськ, костел, польська національна меншина, penpeciï

Національне питання, а також питання релігії є одними з найважливіших у будь-якому суспільстві. Вагомою складовою релігійного життя України $є$ католицизм. Наукове переосмислення процесів, що відбувалися в СРСР у 30-ті роки ХХ ст. по відношенню до Римо-католицької церкви (РКЦ) та польської національної меншини (у нашій державі Католицька церква зазвичай асоціюється 3 польським населенням), є актуальним, бо допоможе уникати подібних проблем на сучасному етапі.

Тема сталінських репресій (у тому числі і щодо РКЦ), об'єктивне вивчення якої було неможливим у радянський період, викликала неабиякий інтерес істориків у часи незалежності України. Вчені досліджували умови, в яких існувала Римо-католицька церква на українських землях у міжвоєнний період, напрямки державної політики щодо релігії та релігійних інституцій. у результаті з'явилися статті Г. Стронського 1 , В. Войналовича 2 ,

\footnotetext{
* Мосюкова Наталія Геннадіївна - кандидат історичних наук, доцент кафедри філософії та політології Національної металургійної академії України (Дніпро, Україна);

ORCID: https://orcid.org/0000-0002-9568-4681; e-mail: nataszafranczeska@gmail.com

${ }^{1}$ Стронський Г. Приречена на мовчання. Римо-католицька церква в Україні в 20-30-і рр. // Людина і світ. 1994. №3-4. С. 17-20.

${ }^{2}$ Войналович В.А. Партійно-державна політика щодо релігії та релігійних інститущій в Україні 1940-1960-х років: політологічний дискурс. Київ: Світогляд, 2005. 741 с.
} 
Е. Бистрицької ${ }^{3}$, Н. Рубльової ${ }^{4}$ й ін. Означена проблема привертає увагу не тільки українських, а і польських вчених. Про це свідчать праці Р. Дзвонковського ${ }^{5}$, Д. Сули ${ }^{6}$ й ін., в яких висвітлено методи, що застосовували більшовики у боротьбі проти РКЦ, репресії проти римо-католицького духовенства і вірян.

Дослідження історії Римо-католицької церкви на регіональному рівні, у тому числі на Півдні України і в окремих його містах, доповнюють та уточнюють знання щодо умов, в яких існувала РКЦ на українських землях. Цій темі присвячені статті В.Ганзуленко ${ }^{7}$ О. Третьякової ${ }^{8}$, В. Стойчева ${ }^{9}$, Н. Буланової ${ }^{10}$ та ін.

Попри зменшення кількості «білих плям» у вивченні проблеми, деякі питання ще досліджені слабо, серед них - історія римо-католицької парафії Дніпропетровська. Означена тема частково висвітлена у публікації Н. Мосюкової ${ }^{11}$.

Метою даної праці є дослідження обставин, в яких існували римо-католики обласного центру в період сталінських репресій, а також уточнення дати та відтворення процедури закриття костелу в умовах, коли документи щодо цієї події відсутні.

Римо-католики оселилися у Катеринославі ще у XIX ст. й у пореформений період їх чисельність постійно зростала. В результаті у місті сформувалася римо-католицька парафія й у 1877 р. був побудований костел св. Йосипа.

Встановлення більшовицької диктатури суттєво ускладнило життя вірян, у результаті значна кількість римо-католиків Катеринослава, переважна більшість яких належала до польської національної меншини, виїхала на історичну Батьківщину.

У 20-ті роки XX ст. комуністична влада не проводила жорстких репресій проти поляків і Римо-католицької церкви, але антирелігійна пропаганда, фінансовий тиск та інші методи, що їх застосовували більшовики по відношенню до релігійних інституцій, «робили свою справу». У 1929 р. «лише 6\% від загальної кількості поляків Дніпропетровська були парафіянами костелу св. Йосипа» ${ }^{12}$.

\footnotetext{
${ }^{3}$ Бистрицька Е.В. Політика радянської влади щодо римо-католицької церкви в 1920-1930-х рр. // Наукові записки [Національного університету «Острозька академія»]. Серія: Історичне релігієзнавство. 2020. Вип. 3. C. 17-32.

${ }^{4}$ Рубльова Н. Антикостьольна кампанія в УСРР: причини, інструментарій, перебіг (кінець 20-их - 30-ті рр.) // 3 архівів ВУЧК - ГПУ - НКВД - КГБ. 1999. № 1/2. С. 388-405.

${ }^{5}$ Dzwonkowski R. Losy duchowienstwa katolickiego w ZSSR. 1917-1939. Martyrologium. Lublin: Towarzystwo Naukowe Katolickiego Uniwersytetu Lubelskiego, 1998. $664 \mathrm{s.}$

${ }^{6}$ Sula D. Kosciol katolicki na Ukrainie w latach 1921-1939. URL: https://depot.ceon.pl/bitstream/handle/123456789/10470/09_Sula_Dorota_Ko\%C5\%9Bci\%C3\%B3\%C5\%82...s.107-128.pdf ${ }_{7}^{7}$ Ганзуленко В.П. Римо-католицька церква на Півдні України за часів державного атеїзму (кінець 20-их - 30-і рр. ХХст.) // Наукові записки національного університету «Острозька академія». Серія «Історичне релігіезнавство». 2014. Вип. 10. С. 62-73.

${ }^{8}$ Tретьякова О.А. Становище Римо-католицької церкви Півдня УСРР в міжвоєнні роки // Науковий вісник Миколаївського національного ун-ту ім. В.О. Сухомлинського. Історичні науки. 2013. Вип. 3.35. С. 117-122.

${ }^{9}$ Стойчев В.М. Римо-католицька громада Запоріжжя у 1920-1930-х pp. // 3 архівів ВУЧК - ГПУ - НКВД - КГБ. 2012. № 2. C. 300-349.

${ }^{10}$ Буланова Н. Римо-католицькі громади та клір на Катеринославщині в 1920-х рр.: взаємини з владою // Історія релігій в Україні: актуальні питання. Львів: Логос, 2019. С. 43-50.

${ }^{11}$ Мосюкова Н.Г. Катеринославська (Дніпропетровська) римо-католицька парафія у 20-ті роки XX сторіччя // Старожитності Лукомор’я. 2021. №1. С. 25-33. DOI: https://doi.org/10.33782/2708-4116.2021.1.45

${ }^{12}$ Мосюкова Н.Г. Вказ. праця. С. 33.
} 
В кінці 20-х років XX ст. влада відмовилася від вказаної вище політики і почала новий етап боротьби проти церкви (в тому числі і РКЦ). Так, у грудні 1927 р. на XV з'їзді ВКП(б) «устами тов. Сталина сигнализировалось ослабление антирелигиозной пропаганды» ${ }^{13}$. У 1928 р. НКВС УСРР, ігноруючи реальну ситуацію щодо зростання кількості релігійних громад (принаймні римо-католицьких), зробив висновок про «згасання релігійного впливу в УСРР» (для цього порівняли чисельність молитовних будинків у 1914 і 1927 роках) ${ }^{14}$. У документі також зазначено, що «зменшення кількості членів релігійних громад спричинилось до зменшення матеріальних прибутків релігійних організацій, а, значить, скоротило потребу в молитовних будинках» ${ }^{15}$. Це було своєрідним «обгрунтуванням» необхідності закриття культових споруд. Католицьку церкву віднесли до «класових противників, експлуататорських елементів» 16 «найбільш непримиримих ворогів жовтневої революції, Радянського Союзу та соціалізму» ${ }^{17}$. Такі характеристики ідеологічно обгрунтовували репресії проти РКЦ.

Юридичне підгрунтя посиленню репресій надавав новий Карний кодекс, прийнятий у 1927 р., який давав, за словами Д. Сули, «необмежені можливості для засудження» ${ }^{18}$. Серед документів, що закріпили «найжорстокіші положення щодо релігійних об’єднань» В. Войналович називає резолюцію ЦК КП(б)У від 30 червня 1928 р. «Про релігійний рух і антирелігійну пропаганду» та лист ЦКВКП(б) від 24 серпня 1929 р. «Про заходи щодо посилення антирелігійної роботи» ${ }^{19}$.

Як і в попередні роки, релігійні спільноти повинні були надсилати до адміністративного відділу окружного виконкому списки членів громади по встановленій формі, тобто вказати прізвище, ім'я, по-батькові, стать, вік, національність, громадянство, освіту, соціальний і майновий стан, час вступу до громади, адресу ${ }^{20}$. При цьому документ, датований 1928 р. i адресований римо-католицькій громаді, містив ухвалення про те, що «установи релігійного культу, в яких виконуються музичні та вокальні твори композиторів, повинні сплачувати авторський гонорар за виконання цих творів» ${ }^{21}$. 3 користування релігійних громад вилучали всю літературу, що не мала прямого відношення до культу та його відправ, адміністративний відділ Дніпропетровського окрвиконкому наказував райадмінвідділам округи стежити за «службовцями римо-католицього культу», які, на думку цієї організації, «розхищають культмайно та зібрані грошові суми, скривають церковні цінності» (збережено мову документу) 22.

Постанова Президії Всеросійського ЦВК і РНК РСФРР «Про релігійні обєднання» (8 квітня 1929 р.) створювала ще більш сприятливі умови для закриття культових споруд, а «6 лютого 1930 року Антирелігійна комісія ЦК ВКП(б) під керівництвом О. Ярославського прийняла рішення переглянути постанову від 8 квітня 1929 року... 3 метою спрощення процесу закриття

\footnotetext{
${ }^{13}$ Держархів Дніпропетровської області (далі - ДАДО). Ф. П-18. Оп. 1. Спр. 966. Арк. 73.

${ }^{14}$ Центральний державний архів вищих органів влади і управління України (далі - ЦДАВО України). Ф. 5. Оп. 3. Спр. 1064. Арк. 20.

${ }^{15}$ ЦДАВО України. Ф. 5. Оп. 3. Спр. 1064. Арк. 20.

${ }^{16}$ Стронський Г. Вказ. праця. С. 19.

${ }^{17}$ Sula D. Op. cit.

${ }^{18}$ Ibidem.

${ }^{19}$ Войналович В. Вказ. праця. С. 101.

${ }^{20}$ ДАДО. Ф. Р-1407. Оп. 1. Спр. 24. Арк. 10.

${ }^{21}$ Ibid. Арк. 32.

${ }^{22}$ Ibid. Арк. 32-33.
} 
культових споруд... Рішення Антирелігійної комісії підкріпила постанова ВЦВК і РНК СРСР “Про боротьбу з контрреволюційними елементами в керівних органах релігійних об'єднань”» ${ }^{23}$.

1929 р. був переламним в історії СРСР, переламним, на думку дослідників, він став і у ставленні держави до Римо-католицької церкви, а Г.Стронський додає, що «апогей антикатолицьких дій припав на 1930 рік» ${ }^{24}$.

Характерною рисою періоду було посилення антирелігійної пропаганди. Вагому роль у цій діяльності відіграла Спілка войовничих безвірників. На Дніпропетровщині вона була заснована у 1927 р., а у 1929 р. налічувала більше 15 тисяч членів ${ }^{25}$. «Безвірники» називали релігійні організації контрреволюційними, релігію - «величезним гальмом», молитовні будинки - «будинками мракобісся», закликали до цілковитої ліквідації «релігійного дурману» ${ }^{26}$.

Комуністична партія не тільки виводила на боротьбу з церквою «безвірників», а ставила завдання «ув'язки роботи осередків СБ (Спілки безвірників - Авт.) з роботою громадських і радянських установ та організацій» ${ }^{27}$. Проводилися спеціальні конференції серед червоноармійців, представників нацменшин, молоді та дітей; антирелігійні вечори та інсценування. До пропаганди залучали засоби масової інформації - радіо, газети, журнали. Не відмовлялися і від старих (тих, що застосовували у 1920-ті роки) методів агітації доповідей, лекцій, бесід, але якщо у 1920-ті роки партія «закидала сіті» пропаганди безсистемно й «обробляла» тих, хто «попався» 3 власної волі або випадково, то у 1930-ті роки вона намагалася донести свою антирелігійну ідеологію до кожного району, до кожного робочого місця та школи.

У 1929-1930 рр. мала місце потужна хвиля арештів католицького духовенства. У 1929 р. було заарештовано і настоятеля Дніпропетровського костелу М. Вольфа. Його звинуватили в агітації проти радянської влади, шпигунстві, навчанні дітей Закону Божому, проведенні антисемітської роботи ${ }^{28}$ та засудили до 10 років таборів, а у 1937 р. розстріляли.

у 1930 р. настоятелем Дніпропетровської парафії було призначено Вікентія Сквирецького. Отже, римо-католицька парафія і костел в обласному центрі діяли, але римо-католики Півдня України повною мірою відчули на собі початок нового періоду стосунків з владою - у 1929 р. було закрито костел у Кам'янському, який «став першим офіційно закритим римо-католицьким храмом на Дніпропетровщині...»" , у 1930 р. - у Запоріжжі ${ }^{30}$, у 1931 р. - в Херсоні ${ }^{31}$, у 1933 р. - в Єнакієвому ${ }^{32}$, того ж року - у Маріуполі ${ }^{33}$. «У Миколаєві римо-католицька церква діяла до 1934 року..., але фактично діяльність костелу

\footnotetext{
${ }^{23}$ Бистрицька Е.В. Вказ. праця.

${ }^{24}$ Стронський Г. Вказ. праця. С. 20.

25 ДАДО. Ф. П-18. Оп. 1. Спр. 966. Арк. 10, 18.

${ }^{26}$ ДАДО. Ф. П-18. Оп. 1. Спр. 966. Арк. 1, 4, 11, 59.

${ }^{27}$ ДАДО. Ф. П-7. Оп. 1. Спр. 1278. Арк. 140.

${ }^{28}$ Мосюкова Н.Г. Священники Катеринославської (Дніпропетровської) римо-католицької парафії (радянський період) // Науковий щорічник «Історія релігій в Україні». Львів: Логос, 2020. Вип. 30. С. 206.

${ }^{29}$ Буланова Н. Вказ. праця. С. 49.

${ }^{30}$ Стойчев В.М. Вказ. праця. С. 310.

${ }^{31}$ Третьякова О.А. Вказ. праця.

${ }^{32}$ ЦДАВО України. Ф. 1. Оп. 9. Спр. 48. Арк. 3.

${ }^{33}$ ЦДАВО України. Ф. 1. Оп. 9. Спр. 49. Арк. 1.
} 
припинилася після арешту настоятеля Зиско Х.Л. 25 вересня 1933 року» ${ }^{34}$. Г. Стронський зазначає, що «до 1933 року в Україні було зачинено дві третини костьолів» ${ }^{35}$.

Є версія, що і Дніпропетровський костел був закритий саме у цьому році. Таку інформацію дає у своїй праці В. Старостін з посиланням на О. Слоневського ${ }^{36}$. А. Фоменко не називає точної дати події, вказує тільки, що костел було закрито наприкінці 1920-х - на початку 1930-х років ${ }^{37}$. О. Слоневський, вивчаючи документ про кількість церков i молитовних домів на вересень 1933 р. у Дніпропетровську, пише, що документ «не лишає сумнівів у тому, що римо-католицький костел був закритий у вересні 1933 року» ${ }^{38}$.

Вважаємо, що не викликає сумнівів тільки той факт, що костел діяв на момент 1.09.1933 р., бо про це чітко написано у звіті ${ }^{39}$. У документі є інформація, що за період 3 1920 р. до жовтня 1933 р. було закрито «три інших церкви» (крім визначених церков, синагог, сектантських молитовних домів ${ }^{40}$. О. Слоневський вважає, що «три інших храми», які були закриті, це - костел, кірха та старовірська церква ${ }^{41}$.

У документі представлено розгорнутий список церков, які закривались (по роках, у тому числі й у вересні 1933 р.). Костелу в цьому списку немає (і кірхи також). В означеному переліку $є$ вісім номінацій: старослов'янські церкви, соборно-єпископські церкви, синодальні церкви, старовірські церкви, єврейські синагоги, караїмська кенаса, мусульманська мечеть і сектантські молитовні дома. У підсумках визначено, що закрито 12 сектантських домів. Ця цифра збігається 3 підрахунками по роках. Окремо позначені закриті синагоги. Підсумкова цифра закритих за звітний період синагог (36) збігається 3 підрахунками по роках. Під «закритими церквами» у підсумковому списку слід розуміти старослов'янські, соборно-єпископські та синодальні церкви. Саме так підказує логіка і точний збіг цифр (29) у звіті за 1920-1933 рр. і підрахунках по роках. У списку залишилися три культові споруди, не названі конкретно у підсумках, тобто «інші». Вважаємо, що це старовірська церква, караїмська кенаса та мусульманська мечеть. Старовірська церква була закрита у вересні 1933 р., кенаса - у 1930 р., мечеть - у період з 1924 по 1928 роки ${ }^{42}$. Всі розрахунки збігаються з наданими у документі підсумками. Крім того, у звіті за 1.09.1933 р. костел вказаний у списку церков, а не серед «інших» ${ }^{43}$. Отже, костел не був закритий у вересні 1933 р.

Ще одним аргументом на користь більш пізнього, ніж 1933 р. закриття римокатолицького храму в Дніпропетровську є те, що його настоятель був заарештований тільки у 1937 р. Навряд чи влада надовго залишила б на свободі ксьондза, якщо костел вже

\footnotetext{
${ }^{34}$ Третьякова О.А. Вказ. праця.

${ }^{35}$ Стронський Г. Вказ. праця. С. 20.

${ }^{36}$ Старостін В. Історична довідка до проекту реставрації костьолу в ім’я святого Йосипа по пр. К. Маркса, 91 у м. Дніпропетровську. Дніпропетровськ: ГО «Інститут суспільних досліджень», 2010. С. 30.

${ }^{37}$ Фоменко А. Костьол - громадська організація «Слов'янська» / Дніпропетровськ: минуле і сучасне. Дніпропетровськ: Дніпрокнига, 2001. С. 62.

${ }^{38}$ Слоневский A. Жизнь. Смерть. Воскресение. URL: www.snicola.net/wpcontent/uploads/2014/12/Жизнь.Смерть.Воскресение.Переиздание.pdf

${ }^{39}$ ДАДО. Ф. Р-416. Оп. 1. Спр. 173. Арк. 1об.

${ }^{40}$ ДАДО. Ф. Р-416. Оп. 1. Спр. 173. Арк. 6-7.

${ }^{41}$ Слоневский А. Вказ. праця.

${ }^{42}$ ДАДО. Ф. Р-416. Оп. 1. Спр. 173. Арк. 6-7.

${ }^{43}$ Ibid. Арк. 13в.
} 
закритий. Для неї це було небезпечно, бо священник міг продовжити своє служіння у приватних приміщеннях і контролювати це було б набагато важче. Аналіз документів щодо закриття костелів в інших містах Півдня України дозволяє стверджувати, що період між арештом ксьондза та закриттям храму не є довгим і не вимірюється кількома роками.

Звіт про ліквідовані молитовні будинки по місту Дніпропетровську та району дозволяє підтвердити факт посилення репресій щодо церкви наприкінці 1920-х - на початку 1930-х років. Так, якщо з 1920 по 1924 роки було закрито 19 культових споруд, з 1924 по 1928 роки - 13, то за один 1929 р. - 15, майже стільки ж - 14 - у 1930 р. У 1931 р. влада ліквідувала набагато менше молитовних будинків - 2, а з наступного року ця кількість знову зросла - 7 у 1932 р. і 10 - за неповний 1933 р. (з них 8 було закрито у вересні). На 1 жовтня 1933 р. в місті залишилося 11 церков (вважаємо, що серед них костел і кірха), 7 синагог і 4 сектантських молитовних будинки ${ }^{44}$.

На офіційному сайті Римо-католицької церкви України зазначено, що «радянська влада закрила святиню в Дніпропетровську у 1937 році» ${ }^{45}$. Ще одну дату закриття костелу (але без жодних обгрунтувань) назвав Г. Борисов - 23 листопада 1936 p. $^{46}$

Точна дата закриття римо-католицького храму обласного центру автору, на жаль, невідома. Достеменно відомо тільки те, що його закрили не пізніше січня 1937 р. Підстави стверджувати це дає наступна фраза зі справи Вікентія Сквирецького: «...3 січня місяця 1937 р., у зв'язку із закриттям костелу у Дніпропетровську, католицькою організацією була розгорнута велика кампанія, яка формально носила характер вимог вірян про відкриття костелу» ${ }^{47}$.

Викладене вище дає підстави найбільш вірогідним періодом ліквідації римокатолицького храму у Дніпропетровську вважати кінець 1936 р., до того ж закрити храм перед великим святом, у даному випадку перед Різдвом, - є цілком у дусі комуністичної влади. Саме так вчинили, коли відібрали костел у католиків Кам'янського у 1929 р.

За вказаних вище причин не маємо можливості дослідити, як саме закривали римокатолицький храм у Дніпропетровську, але можна «намалювати схему» цього процесу, користуючись документами про закриття костелів в інших містах Півдня і Сходу України.

Як зазначає В. Ганзуленко, «спочатку проводилося обстеження технічного стану споруди... і церковна будівля визнавалася аварійною й непридатною для проведення богослужінь..., далі релігійні громади мали за власний кошт сплатити капітальний ремонт будівлі та пов'язані 3 ним видатки» $^{48}$. Саме так було у Маріуполі: 17 жовтня 1932 р. до римо-католицького храму прийшла комісія з метою перевірки «виконання ремонтних робіт» і склала акт (цією подією починається справа про закриття костелу). Рівно через п'ять місяців комісія повернулася і «з'ясувала», що «вследствие непроизведенного ремонта здание находится в неудовлетворительном состоянии и требует ремонта» ${ }^{49}$. Серед завдань по ремонту були: «покрыть фронтонные парапеты железом, перетереть штукатурку наружных стен, цоколя и купола..., сделать цементные отливы для отвода воды от стен здания..., застеклить до 50\% всех оконных переплетов» і таке інше

\footnotetext{
${ }^{44}$ Ibid. Арк. 6.

${ }^{45}$ Костели і каплиці України. URL: https://www.rkc.in.ua

${ }^{46}$ Борисов Г. Polska на берегах Днепра // Вісті Придніпров'я. 2005. 24 березня.

${ }^{47}$ ДАДО. Ф. Р-6478. Оп. 2. Спр. 8739. Арк. 43.

${ }^{48}$ Ганзуленко В. Вказ. праця. С. 66.

${ }^{49}$ ЦДАВО України. Ф. 1. Оп. 9. Спр. 49. Арк. 13.
} 
«...в сумі до 4000 карб.» ${ }^{50}$. Потім до міськради було надано документ 3 проханням відібрання у громади молитовного будинку, бо за нею «рахується недоплата по місцевих податках, податок з будівлі та ренти в сумі 600 карб.» ${ }^{51}$. Сьомого квітня 1933 р. влада констатувала, що «п'ятдесятка відмовилася зробити ремонт і відмовилася від користування костелом взагалі ${ }^{52}$.

3 фінансового тиску починалося і закриття єнакієвського римо-католицького храму, закінчилося відмовою «п'ятдесятки» робити ремонт і, власне, закриттям цієї релігійної споруди $^{53}$. Слід зазначити, що і в Маріуполі, і в Єнакієвому відразу після періоду фінансового тиску проводилися антирелігійні заходи на підприємствах міста, як, наприклад, на заводі КОВЧАВШТАМП та швейній фабриці у Маріуполі, які закінчувалися вимогою закрити культові споруди, їх називали «вогнищами дурману контрреволюції», які використовує «купка експлуататорів» ${ }^{54}$.

Навіщо владі треба було влаштовувати «цирк» зі зборами робітників і колективним засудженням релігії, якщо прийнята 8 квітня 1929 р. постанова «Про релігійні обєєнання» давала достатньо важелів для закриття релігійних споруд? Так, договір на користування будівлею та майном культу можна було розірвати в разі відмови вірян від ремонту ${ }^{55}$. Отже, можна припустити, що католики і після фінансового тиску не завжди давали згоду на закриття костелу. Тоді «в бій йшла важка артилерія» - суспільна думка зі звинуваченнями у контрреволюції, а наслідки таких звинувачень у 1933 р. віряни добре знали і розуміли, що шансів на збереження релігійної споруди їм просто не залишають. Вважаємо, що влада «страхувала» себе на випадок, якщо парафіяни і за умов фінансового тиску не дадуть згоди на закриття храму. Застосування статті закону про можливість ліквідації молитовної будівлі, якщо вона потрібна для державних або суспільних потреб ${ }^{56}$, взагалі не передбачала згоди вірян, але могло викликати зайві для СРСР звинувачення в світі, тому владі вигідніше було застосовувати тактику, що їі використали для закриття костелів у Кам'янському, Маріуполі та Єнакієвому.

Підготовка до закриття римо-католицького храму у Кам'янському, яка відбувалася 3 1928 р., тривала довше, ніж у згаданих вище містах. Закрити планували відразу чотири релігійні споруди - церкву, синагогу, костел і кірху. Збір підписів у цехах заводу не дав бажаного результату (було зібрано лише 3574 підписи), тому у 1929 р. розпочали «крупную кампанию по обработке общественного мнения», після цього було обіцяно, що «по цехам... будут внесены единогласные постановления о закрытии молитвенных помещений». Але і ця веснянолітня кампанія (йдеться про заходи на Великдень та Трійцю - Авт.), яка включала дискредитацію ксьондза (був заарештований восени 1929 р.), не дала очікуваного результату, бо «за зачинення кірхи не було жодного лютеранського підпису». Владу це не

\footnotetext{
${ }^{50}$ Ibidem.

${ }^{51}$ Ibid. Арк. 12.

${ }^{52}$ Ibid. Арк. 1.

${ }^{53}$ ЦДАВО України. Ф. 1. Оп. 9. Спр. 48. Арк. 6, 19.

${ }^{54}$ ЦДАВО України. Ф. 1. Оп. 9. Спр. 49. Арк. 10-11.

${ }_{55}$ «0 религиозных объединениях». Постановление Всероссийского Центрального Исполнительного Комитета и Совета Народных Комиссаров РСФСР, 8 апреля 1929 г. URL: https://www.1000dokumente.de/?c=dokument_ru\&dokument=0007_rel\&object=translation\&

${ }^{56}$ Ibidem.
} 
зупинило, отже, прийняли рішення «провести роботу... за закриття одночасно всіх чотирьох молитовних домів, бо інакше закриття кірхи оформити неможливо» ${ }^{57}$.

Справу «було зроблено» у листопаді-грудні 1929 р. За закриття молитовних споруд поставили свій підпис 20560 осіб (загальна кількість тих, які користувалися виборчими правами у місті - 23871 особа), серед них 662 поляка (із загальної кількості 2116 осіб). Члени релгромади (у 1929 р. налічувала 124 особи) документ не підписали ${ }^{58}$.

«Страховка» влади «суспільною думкою» не була для неї зайвою. Не тільки лютерани не хотіли ставити свої підписи за закриття молитовних споруд, а і парафіяни костелу св. Миколая. Не всі поляки міста, навіть ті, які не були парафіянами римо-католицького храму, дали згоду на його закриття. Про це свідчать наведені вище цифри.

Порівняльний аналіз механізму закриття релігійних споруд (принаймні католицьких) у 1929 і 1933 роках, зроблений на прикладі храмів у Кам'янському - з одного боку, та Маріуполі та Єнакієвому - з іншого, дозволив простежити еволюцію процедури закриття релігійних споруд. Вважаємо, що використання матеріалів закриття костелу тільки у Кам'янському в якості прикладу за 1929 р., не $є$ суттєвою перешкодою в означеному дослідженні, бо центральна влада контролювала діяльність місцевої та не дозволяла «самодіяльності» у цих справах. Так, у 1927 р. НКВС не дозволила Дніпропетровському РВК (районний виконавчий комітет - Aвт.) самовільно закрити молитовний будинок у селі

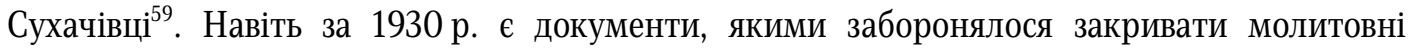
будинки, але йшлося про «незаконне закриття», «без санкції ОВК і ВУЦВК», у подібних випадках дозволяли відкривати молитовні будинки «за вимогами населення», а завідуючим райадмінвідділів «оголосили догану» ${ }^{60}$.

Вважаємо, що зазначене вище не є свідченням того, що влада дотримувалася принципів свободи совісті, вона просто хотіла спочатку «підготувати підгрунтя» під закриття храмів, тобто добряче «промити мізки» вірянам, залякати їх, а потім закрити культові споруди їх руками. Отже, існувала визначена процедура, відхилятися від якої не дозволяли, а матеріали щодо закриття молитовних будинків у Кам'янському лише їі ілюструють. Порівняльний аналіз дає підстави стверджувати наступне:

1. Попри брутальність і підступність дій влади в обох випадках, методи дещо відрізнялися.

2. У 1929 р. перед закриттям костелу проводилася потужна агітаційна робота, збирали підписи, особливу увагу приділяли тому, щоб були підписи представників національних меншин, у 1933 р. - достатньо було голосування на загальних зборах кількох підприємств населеного пункту.

3. У 1933 р. справи щодо закриття костелів починалися з фінансового тиску на релігійну громаду, в результаті чого «п'ятдесятка» відмовлялася від утримання храму, у 1929 р. релгромада «дозволила собі» не підписувати клопотання про закриття.

4. У 1929 р. у Кам'янському підставою для закриття костелу були «вимоги трудящих» та відсутність ксьондза, у Маріуполі та Єнакієвому у 1933 р. - все ті ж «вимоги трудящих» і

\footnotetext{
${ }^{57}$ ДАДО. Ф. Р-1278. Оп. 1. Спр. 19. Арк. 21.

${ }^{58}$ Ibidem. Арк. 65, 49, 54.

${ }^{59}$ ДАДО. Ф. Р-1407. Оп. 1. Спр. 13. Арк. 7.

${ }^{60}$ ДАДО. Ф. Р-1407. Оп. 1. Спр. 34. Арк. 14.
} 
відмова релгромади використовувати храм. У даному випадку наявність священника не стала перешкодою для закриття молитовного будинку (ксьондз Адам Вагнер, який на той момент служив у Маріуполі' ${ }^{61}$ був заарештований тільки у 1934 p. $^{62}$ ).

5. У 1929 р. окрвиконком звертався до Президії ВУЦВК з проханням про надання санкції на закриття молитовного будинку, у 1933 р. - після візи Президії облвиконкому справу відправляли до Секретаріату ВУЦВК «на затвердження» ${ }^{63}$, тобто процес було спрощено.

6. Певним «стримуючим моментом» для закриття костелів у кінці 1920-х - на початку 1930-х років був міжнародний чинник. У документах щодо ліквідації молитовних будинків у Кам'янському про це говорилося прямо: «...місцеві працівники із задоволенням закрили б костел, але побоюються міжнародних ускладнень» ${ }^{64}$.

7. у Кам'янському відібрану будівлю планували віддати під клуб для поляків ${ }^{65}$, у Маріуполі - під клуб для поляків і німців ${ }^{66}$. Так влада нав'язувала думку про те, що вона не воює з представниками національних меншин, а, навпаки, дбає про їхній культурний розвиток (одним із аргументів необхідності закриття молитовних будинків у Кам'янському було те, що у місті не вистачає помешкань для культурно-освітньої роботи ${ }^{67}$ ).

Дніпропетровський костел закривали у 1930-ті роки, отже, відбувалося це, ймовірно, за спрощеною процедурою. У довоєнний час, - зазначає А. Фоменко, - у будівлі костелу була майстерня з нарізки скла ${ }^{68}$. Отже, не клуб для поляків, як це часто бувало у кінці 1920-х - на початку 1930-х років, а майстерня. Дійсно, не було сенсу влаштовувати клуб для представників національної меншини, проти якої у другій половині 1930-х років «повним ходом» відбувалися репресії. I це є ще одним, нехай не «вбивчим», але аргументом на користь того, що римо-католицький храм в обласному центрі закрили у другій половині 1930-х років.

У постанові «Про релігійні об'єднання» було визначено, як розподіляється культове майно при ліквідації молитовної будівлі. Майже все воно передавалося державним інституціям - фінансовим органам, органам освіти й ін. ${ }^{69}$ «Иконы, облачения, хоругви, покровы и т.п., имеющие специальное значение при отправлении культа» за законодавством передавали вірянам для переносу в інші молитовні будинки того ж культу ${ }^{70}$. у 1930 р., як вказує Н. Рубльова $з$ посиланням на Бюлетень НКЮ УСРР, крайовим інспекторам охорони пам'яток культури пропонували в церквах, що закриваються, за актом вилучати культурно - мистецькі речі й передавати їх до місцевих музеїв ${ }^{71}$.

Вірогідність того, що культове майно Дніпропетровського костелу опинилося в іншому римо-католицькому храмі, є зовсім невеликою, бо більшість їх на той момент (після 1933 р.)

\footnotetext{
${ }^{61}$ ЦДАВО України. Ф. 1. Оп. 9. Спр. 49. Арк. 13.

${ }^{62}$ Dzwonkowski R. Вказ. праця. С. 495.

${ }^{63}$ ЦДАВО України. Ф. 1. Оп. 9. Спр. 49. Арк. 4.

64 ДАДО. Ф. Р-1278. Оп. 1. Спр. 19. Арк. 20.

${ }^{65}$ Ibid. Арк. 54.

${ }^{66}$ ЦДАВО України. Ф. 1. Оп. 9. Спр. 49. Арк. 3.

${ }^{67}$ ДАДО. Ф. Р-1278. Оп. 1. Спр. 19. Арк. 49.

${ }^{68}$ Фоменко А. Вказ. праця. С. 62.

${ }^{69}$ «О религиозных объединениях»...

${ }^{70}$ Ibidem.

${ }^{71}$ Рубльова Н. Вказ. праця. С. 394.
} 
була вже закрита. Досить великою є ймовірність передачі означеного майна до музею. На користь цієї версії говорить не тільки рекомендація, що її надавали крайовим інспекторам охорони пам'яток культури, а й те, що у фондах музею в Дніпрі зберігаються культові предмети, які використовуються у римо-католицьких храмах. Названі предмети можна було побачити на виставці, організованій працівниками історичного музею ім. Дмитра Яворницького. Точно встановити, як саме там опинилося майно костелу, зараз важко, але найбільш вірогідною «дорогою» є та, яка з'єднує музей міста 3 костелом св. Йосипа.

У 30-ті роки XX ст. посилилися репресії не тільки проти РКЦ, а й проти польської національної меншини, що складала основну частину пастви костелу. У червні 1937 р. був заарештований настоятель парафії св. Йосипа В. Сквирецький, а у серпні 1937 р. влада розпочала «широку операцію» проти польського населення, яку планували закінчити у трьохмісячний термін ${ }^{72}$.

Наявність у Дніпропетровську військових заводів і великих промислових підприємств полегшувало НКВС виконання завдання пошуку об'єктів, на яких «шкідники» могли здійснювати «диверсії. На допитах у НКВС була «отримана інформація» про існування так званого «Лівобережного центру» ПОВ (Польська організація військова - Авт.), що «охоплював своєю діяльністю такі міста, як Дніпропетровськ, Запоріжжя та інші» і діяв «під прапором Римо-католицької церкви». Центр організації «розмістили» у Дніпродзержинську ${ }^{73}$.

За версією НКВС безпосередньо у Дніпропетровську диверсійною діяльністю на заводах ім. К. Лібкнехта та Комінтерн займався Едуард Білоскурський, а контрреволюційну роботу католицької організації очолював ксьондз Сквирецький, який «об’еднував навколо себе найбільш реакційну частину польського населення» ${ }^{74}$. У справі настоятеля парафії св. Йосипа зазначено, що «учасники організації проводили серед польського населення активну контрреволющійну роботу, поширювали... чутки щодо переслідувань поляків і Католицької церкви в СРСР ${ }^{75}$. По справі ксьондза проходили і віряни Дніпропетровської римо-католицької парафії - костельні активісти ${ }^{76}$.

Переважна більшість заарештованих у ході польської операції в Дніпропетровській області була засуджена до вищої міри покарання ${ }^{77}$. Настоятеля костелу В. Сквирецького розстріляли 19 вересня 1937 p. $^{78}$ У цей день були розстріляні також Едуард Білоскурський, Мар'ян Вальчак, Болеслав Рульковський ${ }^{79}$, які проходили по справі Вікентія Сквирецького.

Римо-католицька громада Дніпропетровська, що залишилася без настоятеля, без

\footnotetext{
${ }^{72} 3$ оперативного наказу народного комісара внутрішніх справ СРСР № 00485 про репресії проти польського населення 11 серпня 1937 р. // Реабілітовані історією: У 27 томах. Дніпропетровська область: у 2 кн. Дніпропетровськ: Моноліт, 2008. Кн. 1. С. 215-216.

${ }_{73}^{73}$ ДАДО. Ф. Р-6478. Оп. 2. Спр. 8739. Арк. 42-43.

${ }^{74}$ Ibidem

${ }^{75}$ Ibid. Арк. 43-44.

${ }^{76}$ Ibid. Арк. 21.

${ }^{77}$ Доповідна записка управління НКВС в Дніпропетровській області заступнику наркома внутрішніх справ УРСР про підсумки роботи по розкриттю польського диверсійного підпілля в Дніпропетровській області 12 січня 1938 р. // Реабілітовані історією: У 27 томах. Дніпропетровська область: У 2 кн. Дніпропетровськ: Моноліт, 2008. Кн. 1. С. 217-218.

${ }^{78}$ Мосюкова Н.Г. Священники Катеринославської (Дніпропетровської) римо-католицької парафії... С. 210.

${ }^{79}$ Реабілітовані історією: У 27 томах. Дніпропетровська область: У 2 кн. Дніпропетровськ: Моноліт, 2008. Кн. 2. С. $61,106,809$.
} 
костелу, знекровлена репресіями, на певний час припинила своє існування. Не тільки для цієї парафії, а і для всієї РКЦ в Україні 30-ті роки XX ст. закінчилися трагічно - вона «як суспільна інституція з власною ісрархією, кліром та паствою була повністю ліквідована» ${ }^{80}$.

Таким чином, 3 кінця 20-х років XX ст. тиск на Католицьку церкву посилився по всіх напрямках - від надання антирелігійній пропаганді білыш системного характеру до масового закриття костелів та арештів священників.

Римо-католицька спільнота Дніпропетровська, ймовірно, проіснувала значно довше більшості громад Південної України. I хоча точну дату закриття костелу встановити не вдалося, з'ясовано, що він був закритий не раніше жовтня 1933 р. і не пізніше січня 1937 р. Найбілыш вірогідна дата - кінець 1936 р.

В умовах відсутності документів немає можливості точно описати механізм закриття римо-католицького храму в обласному центрі, але аналіз документів щодо закриття інших костелів дозволив стверджувати, що складовими процесу були: потужна агітаційна робота влади, у тому числі серед представників національних меншин, фінансовий тиск на релігійну громаду, «вимога трудящих» закрити храм.

Протягом 1929-1933 рр. процедура ліквідації костелів спрощувалася. У другій половині 1930-х років, можливо, її спростили ще білыше шляхом вилучення із процедури агітаційної роботи серед представників національних меншин, у даному випадку поляків, проти яких відбувалися репресії.

Частиною однієї з польських «диверсійних» організацій влада назвала «католицьку контрреволюційну організацію», а її «керівником» - настоятеля Дніпропетровського костелу В. Сквирецького. Ксьондз Вікентій був розстріляний, а парафія св. Йосипа на певний час припинила своє існування.

\section{Natalia Mosiukova}

\section{Anti-religious policy of the Soviet authority in late 20's - 30's years of XX century (on example of Roman Catholics of Dnipropetrovsk)}

Abstract: The article highlights conditions of the Dnipropetrovsk Roman Catholic parish of St. Joseph in the late 1920-30's. During this period, the authorities pursued a policy characterized by increased anti-religious propaganda, mass closure of religious buildings, and repression against Catholic priests and the Polish population.

In the late of 1920s and 1930s, the foundations were laid for intensifying repression, and anti-religious propaganda became more systemic. The party tried to convey its ideology to every district, to every workplace and school.

Probably, the Roman Catholic community of Dnipropetrovsk lasted longer than most communities in southern Ukraine. The exact date of closing the church in the regional center, unfortunately, is unknown, but the arguments presented in this article allow us to consider the most probable date to be the end of 1936. In absence of documents, it is not possible to accurately describe the mechanism of closing the Roman Catholic church in Dnipropetrovsk,

\footnotetext{
${ }^{80}$ Рубльова Н. Ліквідація в Україні ієрархії Римо-католицької церкви (кінець 1917 - 1937 рр.) // 3 архівів ВУЧКГПУ-НКВД-КГБ. 2000. № 2/4 (13/15). С. 328.
} 
but analysis of documents on closure of other churches revealed that the components of this process were: strong propaganda work of the authorities, including close the temple.

During 1929-1933 the procedure of liquidation of churches was simplified. In the second half of 1930s, it may have been further simplified by removing from the campaign procedure among members of national minorities, in this case Poles, who were being repressed. The authorities called the "Catholic counter-revolutionary organization» part of one of the Polish «subversive» organizations, and its «leader» - the rector of the Dnipropetrovsk church V. Skvyretsky. Priest Vincent was shot.

Parish of St. Joseph, left without an abbot, without a church, bloodless by repression, ceased to exist for a while.

Keywords: Roman Catholics, Dnipropetrovsk, church, Polish national minority, repressions 